\title{
The phenomenon of entrepreneurial leadership in gazelles and mice: a qualitative study from Bosnia and Herzegovina
}

\author{
Ramo Palalic \\ Faculty of Business and Administration, \\ Department of Management, \\ International University of Sarajevo, \\ Building B, Office F1.14, \\ Hrasnicka cesta 15, 71210 Ilidza, \\ Sarajevo, Bosnia and Herzegovina \\ Email: rpalalic@ius.edu.ba
}

\begin{abstract}
This study examines the entrepreneurial leadership and business performance in gazelles and mice, using stratified purposive sampling from three sectors: manufacturing, sales and services. Findings suggest that gazelles are more in favour of applying entrepreneurial leadership compared to mice. However, both of them need improvement. Gazelles need to maintain a constant sustainable growth in the market while mice should transform themselves into gazelles. It can be done by creating a positive synergetic effect of entrepreneurial leadership to business performance in both types of firms, in the long term. Likewise, Bosnian government should pave the way for better business surroundings and to promote entrepreneurship development in the region. On the contrary, the government of Bosnia and Herzegovina $(\mathrm{B} \& \mathrm{H})$ seems to maintain a status quo or even tends to shackle the entrepreneurial activities and opportunities in its business environment.
\end{abstract}

Keywords: entrepreneurial leadership; gazelles; mice; transformational leadership; entrepreneurial orientation; business performance; SMEs; Bosnia and Herzegovina; $\mathrm{B} \& \mathrm{H}$; entrepreneurship; sustainable growth; business owners; CEOs; managers.

Reference to this paper should be made as follows: Palalic, R. (2017)

'The phenomenon of entrepreneurial leadership in gazelles and mice: a qualitative study from Bosnia and Herzegovina', World Review of Entrepreneurship, Management and Sustainable Development, Vol. 13, Nos. 2/3, pp.211-236.

Biographical notes: Ramo Palalic is an Assistant Professor at Faculty of Business and Administration, Management Department, International University of Sarajevo, Bosnia and Herzegovina. He teaches at both undergraduate and postgraduate level in the area of entrepreneurship and small business management, marketing and international management. His research interest covers entrepreneurship, small and medium enterprises, leadership, marketing and international management. He has authored and co-authored several articles in international journals. 


\section{Introduction}

Globalisation requires leaders, business owners and managers to be aware of change in the global business environment. No business can survive without a clear vision established by the company's leadership and supported by entrepreneurial actions. This means that the leader of a company, which could be a business owner, CEO, general manager or director, should be aware of his capabilities and leadership styles, as well as his final outcomes. Accordingly, they should be innovative, proactive, and risk takers when necessary. These characteristics are most likely possessed by astute managers in companies who use their capabilities fully, enabling growth and rapid development within firms while creating sustainable businesses.

The entrepreneurial orientation (EO) dimensions and transformational leadership (TL) style in earlier works are used singularly or in combination when measuring correlation with an effect on business performance of small and medium enterprises (SMEs). Many of the findings on entrepreneurial orientation (Miller, 1983; Covin and Slevin, 1988; Lumpkin and Dess, 2001; Wiklund and Shepherd, 2005, Palalic and Busatlic, 2015) as well as transformational leadership style (Bass and Avolio, 1992, 1994, 1996, 1997, 2000; Yang, 2008; Jandaghi et al., 2009; Chandrakumara et al., 2009; Fazli et al., 2012; Rao, 2012; Aziz et al., 2013a, 2013b) suggest that this orientation and transformational leadership style are positively affecting the growth and development of SMEs.

Bass and Avolio (2001, p.1) claim that "several thousand leaders in the private sector and community leaders in the public sector" (USA) have undertaken training in full leadership elements, transformational and transactional leadership. This demonstrates the importance of leadership, and the researcher believes that it is the same for SMEs in Bosnia and Herzegovina (B\&H).

Based on the fact that gazelles are in reality those regardless of their size, it is important to examine whether the EO dimensions and TL style are correlated to business performance that leads to fast growth (for this research over $10 \%$ annually in a sequence of three years). However, mice should not be neglected in any research (Neumark et al., 2011), and it is the same for this study also.

One may think that if a firm is a medium enterprise (ME), it is immediately granted that it is associated with high business growth. On the other hand, if it is a small enterprise (SE), the firm may be characterised as a low-growth enterprise. However, there are companies and ventures that demonstrate high growth regardless of their size, achieving an annual growth of at least $10 \%$ and more. These firms are considered as fast growing companies, or gazelles (Birch, 1979). A broad importance of gazelles' existence and promoting their new comers may be deemed in the first instance as being job creators essential to an economy. Mice are less important; however, although they have slow growth and create fewer jobs, they are still job creators (Neumark et al., 2011).

Entrepreneurial orientation dimensions as well as transformational leadership style have been found important when the business performance of SMEs is concerned (Covin and Slevin, 1988; Lumpkin and Dess, 2001; Wiklund and Shepherd, 2005; Yang, 2008; Rao, 2012, Aziz et al., 2013a; 2013b). Small and medium enterprises are important for a national economy, and literature has been found on those SMEs which contribute the most to the employment rate of a country (Birch, 1979; Neumark et al., 2011). However, no research has been acquired on leadership and managerial practice (extending previous 
studies of entrepreneurial orientation and transformational leadership style) that will advance and transform those SMEs which have slow growth into fast growing ones.

Even though B\&H in former Yugoslavia (FY) was one of the best former republics, and it was industry-based republic, its economy is in transition and passes through a very difficult time. After the state ownership system on which B\&H was based (Dana and Dana, 2003), it is all left on the private sector (entrepreneurs) to re-build the state economy that will be reflected in a better welfare of the whole society. Hence, B\&H needs SMEs that can create any number of jobs, especially those who have fast growth. In this context, there is an urgent need to develop a future entrepreneurial leadership pattern, which is based on the combination of entrepreneurial orientation and transformational leadership. Such a construct would give a comprehensive understanding of these two important phenomena to leaders and managers.

\subsection{Main objectives}

Differing from quantitative research where there is an "attempt to measure something" [Cooper and Schindler, (2014), p.146], the qualitative research objective is to get a deep knowledge about a certain phenomenon (Cooper and Schindler, 2014). The main focus of this approach in the first place is to verify the outcomes of the previous quantitative data results by qualitative research method, using the semi-structured interviews. Also, the research aims to obtain contextualised, in-depth understanding of entrepreneurial orientation and transformational leadership phenomena in fast (gazelles) and slow growing (mice) SMEs, which may have an association with business performance and growth. In this study, the author explores views of top management who are important people among company's key movers, known as leaders and managers.

Thus, the main objectives of this qualitative study are:

1 to examine EO dimensions and TL style as mediating role in sustainable growth of gazelles and mice

2 to identify relationship between EO dimensions and TL style

3 to derive managerial implications for top management

4 to recommend strategic moves to $\mathrm{B} \& \mathrm{H}$ government regarding the entrepreneurship and SMEs' development.

In order to achieve these objectives, the researcher uses qualitative approach applying semi-structured interview.

\section{Theory and research propositions framework}

\subsection{Gazelles and mice}

There is scant literature to be found that treats and analyses gazelles and mice, what causes their fast and high growth, and whether it is EO or TL, or both of them simultaneously. Harms and Ehrmann (2009) explored the case of German gazelles. They confirm the influence and effect of EO and entrepreneurial management (EM) on business performance (growth) and innovativeness. However, they did not consider the 
case of mice. The presence of TL styles with their relationship to business performance was not explored. Other literature that shows the importance of TL to gazelles and mice were not found at the moment of this study. In this study, the researcher follows Davidsson and Henrekson (2002), Palalic and Busatlic (2015) who suggest that gazelles are those which have an annual growth of $5 \%$ or $10 \%$.

\subsection{Synergy of entrepreneurial leadership and business performance of SMEs}

Entrepreneurial orientation is a combination of dimensions that make firms more entrepreneurial, by being proactive, innovative and risk takers in order to gain competitive advantage. "Entrepreneurial firms are those in which the top managers have entrepreneurial management styles, as evidenced by the firms' strategic decisions and operating management philosophies" [Covin and Slevin, (1988), p.218). Conversely, firms which do not pursue this entrepreneurial stream may be described as: "nonentrepreneurial or conservative firms are those in which the top management style is decidedly risk-averse, non-innovative, and passive or reactive" [Covin and Slevin, (1988), p.218]. These entrepreneurial dimensions are innovativeness, proactiveness and risk taking:

- Innovativeness. This implies the propensity for creating new things, creativity in processes and experiments that lead to development of new products or services or even a new set of technological processes (Lumpkin and Dess, 1996).

- Proactiveness. This is being a 'first-mover' in the market, providing possible offerings to customers that will be based on their needs (Lumpkin and Dess, 1996). Once a firm has its advantage of being the 'first-mover', then there is the possibility to 'skim' profit from the market (Zahra and Covin, 1995).

- Risk-taking. This is about "incurring a debt or taking other risk to seize an opportunity". However, for established ventures and large companies it implies "to commit significant resources to a project to ensure higher returns" (Trevis et al., 2009), but only after planning and anticipating all circumstances (Bhide, 2000).

Transformational leadership is related to "moral values of followers in an attempt to raise their consciousness about ethical issues and to mobilise their energy and resources to reform institutions" [Yukl, (2010), p.261]. "Followers are more likely to attribute charisma to leaders who inspire them with emotional appeals than to leaders who use authority or a participative decision process", and thus "charismatic leaders influence people to collectively accomplish great things that initially seemed impossible" [Yukl, (2010), p.263]. Transformational leadership consists of four styles or factors, which are individualised influence (charisma), inspirational motivation, intellectual stimulation and individualised consideration.

- Individualised influence (charisma). Individualised influence (II) makes leaders a role for the followers to trust and follow them on the path to future prosperity. A charismatic leader is an appreciated person in his surroundings, wherein followers recognise this charisma and try to imitate it (Avolio and Bass, 2002).

- Inspirational motivation. The key terms for inspirational motivation are 'team spirit, enthusiasm and optimism' [Avolio and Bass (2002), p.2]. Such an optimistic and charismatic leader is actually motivation for followers, to adopt and support change 
in an organisation for the sake of organisational prosperity, growth and development (Jandaghi, et al., 2009).

- Intellectual stimulation. Transformational leadership is aware of this and tries to encourage 'creativity' [Avolio and Bass, (2002), p.2]. Although creativity can have negative results, transformational leaders stimulate innovative and creative ideas and discourage 'public criticism' [Avolio and Bass, (2002), p.2].

- Individualised consideration. The key terms concerning this transformational dimension are 'coach, mentor, listening, personalised interaction, personality differences' [Avolio and Bass, (2002), p.3]. The leader has a personalised conversation with a follower, therefore he or she feels not just like an employee, and the leader cares about his employees (not just as workers) and performs a lot of teaching and coaching.

- Business performance. Business performance can be archival financial and archival non-financial or self-reported (Knight, 2000). Murphy et al. (1996) and Gupta and Govindarajan (1984) advocate that SMEs' business performance could be measured by both, objective (often-used financial data) and subjective measures (data given by participants subjectively). Covin and Slevin (1988), Lee et al. (2001), Wiklund and Shepherd (2005), and Covin et al. (2006) espoused the use of performance indicators like sales growth rate, employee growth, gross margin, profitability and cash flow. Kraus et al. (2012) uses the growth in number of employees and growth in turnover to measure business performance. The majority of previous researches in regard to measuring business performance have used 'self-reported' measures, which have proven as reliable (Knight, 2000). For the purpose of this study, the measurement of business performance will use the self-reported measures of sales growth.

\subsection{Relationship 1: entrepreneurial orientation and business performance}

A rule of thumb is that a real entrepreneurial firm necessarily needs to perform equally across all three dimensions, and for performance in these dimensions to not differ among themselves (Covin et al. 2006). However, Stetz et al. (2000), Kreiser et al. (2002) and Hughes and Morgan (2007, in Kraus et al., 2012) argue that these dimensions may "vary within the model creating a truly multidimensional model of EO". Lumpkin and Dess (1996) advocate that contribution to business performance of these three dimensions may not necessarily be true under specific circumstances. Therefore, it is necessary that each dimension's effect should be examined separately (Kraus et al., 2012).

Entrepreneurial orientation is positively related to SMEs performance and it helps them to grow (Zahra, 1991; Covin and Slevin, 1988, 1991; Lee et al., 2001; Wiklund and Shepherd, 2003, 2005). According to Kusumawardhani et al. (2009) SMEs with a high level of EO have better performance comparing to those who have a very low level of EO. Brown et al. (2001), Stevenson and Jarillo, (1990) find that entrepreneurial orientation is connected to increased growth of business performance. Wiklund and Shepherd (2005) confirmed the importance of EO in manufacturing, services and retailing firms, suggesting it has a positive relationship with business performance. Similarly, Casillas and Moreno (2010) examined the relationship between EO and business performance in manufacturing and services firms. They found a strong positive relationship to business performance. Rodrigues and Raposo (2011) found that EO 
indirectly (through market orientation) and positively affects business performance of Portuguese SMEs. Recently, Su et al. (2011) as well as Zhang and Zhang (2012) argued a positive relationship between EO and business performance in SMEs. In addition, Kraus et al. (2012) and Kraus (2013) studied manufacturing and services SMEs from the Netherlands, and the findings justified the importance of EO (proactiveness) and its effect on business performance. A meta-analysis research (study on 51 articles published in the field of EO) suggests: "the effects of EO on performance can be regarded as moderately large" (Rauch et al., 2009). The most recent findings where EO has a positive effect on business performance was in Indian SMEs (Gupta and Batra, 2015) as well as Palalic and Busatlic (2015) in B\&H fast and slow growing SMEs. Thomas and Mueller (2000) suggest that the impact of EO on SMEs performance may differ from country to country. The study's aim is to examine these relationships in gazelles and mice in the $\mathrm{B} \& \mathrm{H}$ business environment.

\subsubsection{Innovativeness and business performance}

Organisations strive for long-term achievements through many ways. One of the ways is innovativeness, which is "the predisposition to engage in creativity and experimentation through the introduction of new products/services as well as technological leadership via R\&D in new processes" (Rauch et al., 2009). Simply, it opens horizons of possible, innovative and useful things for success. Thus, many studies stress innovativeness as one of the most important 'strategic orientations' for organisational positive results (Noble et al., 2002; in Tajeddini, 2010). Previous researches on the relationship between innovativeness and business performance suggest that innovativeness plays an important role in SMEs' business performance, which is ultimately reflected in the sustained business growth of SMEs. Tajeddini (2010) studied the hotel industry. In 156 hotels he found that innovativeness in the hotel industry has a positive impact on business performance (profit, sales). Rodrigues and Raposo (2011), in their study of the relationship between EO and business performance, found that innovativeness is one of the crucial components of the EO dimensions. They also found a strong relationship between innovativeness, risk taking and proactiveness. Abazi-Alili et al. (2014) investigated determinants of innovation and their impact on business performance. They found a significant impact of innovation to firm's performance. This has proved Schumpeter's (Schumpeter, 1934) definition of innovation where innovation is seen as introducing new products which requires new positive changes along production line. Besides the micro effect of innovation in firms, innovation helps the growth and development of the whole society (Ramadani et al., 2013a) and even it becomes a cause where a society is protected from the economic crisis (Zulfiu et al., 2015). All these proscriptions are necessary for $\mathrm{B} \& \mathrm{H}$.

\subsubsection{Proactiveness and business performance}

Proactiveness is considered as the first step in the 'entrepreneurial process' (Kraus et al., 2012). It is "an opportunity-seeking, forward-looking perspective characterised by the introduction of new products and services ahead of the competition and acting in anticipation of future demand" (Miller, 1983; in Rauch et al., 2009). A study done on companies from Vietnam and Thailand has found a positive relationship between proactiveness and business performance (Swierczek and Ha, 2003; in Kraus et al, 2012). 
Kraus et al. (2012) investigated 164 Dutch SMEs, in order to find whether SMEs in the global economic crisis (in 2009) exhibited proactive behaviour that could positively contribute to business performance. The research has shown a significant and positive relationship between proactiveness and business performance. It confirmed that proactiveness contributes directly to a change in business performance over time. Li et al. (2009) surveyed 165 entrepreneurs in Taiwan. They examined the relationship between EO dimensions (innovativeness, proactiveness and risk taking) and business performance, through a mediating role of knowledge creation. They uphold the importance of EO, within which proactiveness plays a significant role in creating a positive relationship with business performance. Other researches also confirmed the importance of proactiveness. It has a direct effect on business performance in enterprises (Lee et al., 2001; Wiklund and Shepherd, 2005; Covin et al., 2006; Hughes and Morgan, 2007; Runyan and Swinney, 2008; Lee and Lim, 2009; Lumpkin et al., 2009; Tajeddini, 2010; Casillas and Moreno, 2010; Su et al., 2011; Zhang and Zhang, 2012; Kraus, 2013).

\subsubsection{Risk-taking and business performance}

"Risk-taking involves taking bold actions by venturing into the unknown, borrowing heavily, and/or committing significant resources to ventures in uncertain environments" (Miller, 1983; in Rauch et al., 2009). A measure of risk is balanced, reasonable and somehow bearable since it is previously anticipated (Morris and Paul, 1987) and is not meant for freezing or weakening the firm from its success (Kraus et al., 2012). Risk adverse firms are far away from entrepreneurial strategies, and usually they wait for others to initiate action. Likewise, these firms do not 'exploit risky opportunities' (Keh et al., 2007). Risk taking is found as a significant contributor to business performance of Malaysian technology-based SMEs (Shafinaz et al., 2014), along with innovativeness and proactiveness. Meanwhile, the autonomy dimension has been found as not significant in contributing to a change of business performance.

\subsection{Relationship 2: transformational leadership and business performance}

Jandaghi et al. (2009) compared transformational leadership of successful and unsuccessful companies and found that transformational leadership is significantly higher in successful companies. Rao (2012) has examined 120 SMEs in India and found a significant impact of transformational leadership styles on business performance. Rao (2012) suggests that transformational leadership has a higher impact on business performance compared with transactional leadership. This is due to the nature of these two kinds of leadership. While transactional leadership is a task-award relationship, transformational leadership propagates a task-commitment relationship, which at its root has inspiration led by a charismatic leader (Bass, 1985). Transformational leadership has been noted as superior compared with transactional leadership when 'innovation capacity' is concerned (O'Regan and Ghobadian, 2006). In this study, transformational leadership overrides transactional, human resource and laissez faire leadership styles. Consequently, it provides the ability for a firm to create, learn, stimulate (employees) and launch new products or services more periodically. For such capability, organisational learning and knowledge management are important. In this context, Noruzy et al. (2012) suggest that transformational leadership has a direct effect on organisational learning and knowledge management in manufacturing firms. They also suggest that transformational 
leadership positively affects organisational innovation and performance through organisational learning and knowledge management. It shows that transformational leadership keeps up the discipline of disseminating strategic vision, from top to bottom. Similarly, Michie and Zumitzavan (2012), in their study of 'small-retail-tyre' firms in Thailand, using quantitative and qualitative analysis, reveal that both transformational and transactional style positively affect organisational outcomes. Another study done by Matzler et al. (2008), confirms a positive relationship between transformational leadership innovation, growth and profitability. Similarly, Wang et al., (2011) A meta study of over 113 studies with 117 independent samples suggests that transformational leadership is positively correlated overall 'contextual performance'.

\subsubsection{Individualised influence and business performance}

Wang et al. (2011) argue that between transformational leadership is incorporated into performance Similarly, Chan and Mak (2014) willingly express their support of their leader because he is 'exemplary' leader (Jandaghi et al., 2009). Hence, the charismatic leader is necessary for a firm and it represents both, physical and a psychological factor that influences his followers to be committed whenever is necessary.

\subsubsection{Inspirational motivation and business performance}

A leader is the one from who the company's vision is shared. Being appreciated by the leader, because he has shared this vision, employees are motivated to achieve that vision. In this case the leader is a crucial team player for successful tasks [Avolio and Bass, (2002), p.2]. Very rare is being searched in this context, especially in Bosnian region, on motivational effect of transformational leaders, the researcher presumes that it influences a whole performance in a company in a positive way in the long-term.

\subsubsection{Intellectual stimulation and business performance}

Avolio and Bass (2002, p.3) equalise intellectual stimulation with 'creativity', while conserve 'public criticism'. Teamwork is advised but not criticised for any mistake done. In this process team members are encouraged to think proactively to find out the best solution for certain issues along the chain of adding values to products or services. Thus, finding and understanding the relationship between transformational leadership and creativity helps leader to create a proactive and innovative working atmosphere (Henker et al., 2014). Since creativity and innovativeness are in a mutual relationship (Matzler et al., 2008; Noruzy et al., 2011), the author could assume that intellectual stimulation is important as a natural source of positive influence towards business performance.

\subsubsection{Individualised consideration and business performance}

Leaders should be worried about followers' needs, feelings, and the whole atmosphere within an organisation (Podsakoff et al., 1990). Sharing all problems and issues (positive and negative ones) makes individualised consideration as very important pillar in transforming the organisation. A leader must be a good 'coach, mentor, and listener' to 
observe all personalities that surround him so that he can act according different needs of his followers. Different personalities need different approaches in the communication process. Noises must be avoided that transmitted message (e.g., company's vision) from the leader to a follower stays in its origin. Although, lots of studies support the assumption where individualised consideration can influence business performance, there are no studies that explicitly treat this phenomenon in gazelles and mice, especially in this region. in this context, the author assumes, together with other transformational leadership pillars, that individualised consideration can contribute in adding values to business performance in firms.

\subsection{Synergy of transformational leadership and entrepreneurial orientation}

Yang (2008) examined a relationship between entrepreneurial orientation and business performance, as well as transformational leadership and business performance. Yang (2008) has also found that transformational leadership influences EO and consequently business performance. Yang (2008) confirmed the previous findings that entrepreneurial orientation and transformational leadership styles improve business performance (Covin and Slevin, 1988; Wiklund and Shepherd, 2005; Bass and Avolio, 1992). Engelen et al. (2015) studied 790 SMEs from six different countries. They explored the moderating role of transformational leadership in the context of entrepreneurial coordination and business performance. The results have shown that when employing all four transformational leadership styles, transformational leadership has a positive effect in the relationship between entrepreneurial orientation and business performance. Engelen et al. (2015) confirmed and advanced the previous research idea that EO achievement is dependent on the "top managers' transformational leadership behaviours" (Kearney et al., 2009; in Engelen et al., 2015). Others emphasised 'entrepreneurial leadership'. Gupta et al. (2004, in Koryak et al., 2015) defined entrepreneurial leadership as 'influencing and directing the performance of group members toward achieving those organisational goals that involve recognising and exploiting entrepreneurial opportunities'. It has both sets of features of entrepreneurship as well as leadership. Therefore, this combination by its nature can have a moderating role and positive effect on overall business performance.

Swiercz and Lydon (2002) find a "process by which successful entrepreneurs transform themselves into professional managers". The study suggests that for entrepreneurs to be motivated and keep up with the aspired level of 'growth-driven hightech firms', they need to have leadership competencies such as self-competencies (integrity, company over self, utilising external resources, and creating sustainability) and functional competencies (marketing, finance, operations. An interesting study has been done by Todorovic and Schlosser, (2007) on the leadership-EO-business performance relationship. They revealed that two types of leadership have a diagonally opposite effect. Charismatic (collective) leadership 'amplifies' the relationship EO-business performance, while egocentric (self-enhancing) 'reduces' that relationship.

Based on the above discussion, it is proposed the following:

1 Proposition 1: EO is important and positively is correlated to business performance in gazelles and mice

2 Proposition 2: TL is important and positively affects business performance in gazelles and mice 
3 Proposition 3: gazelles employ EO and TL more compared to mice

4 Proposition 4: synergy of EO and TL is a paramount positive effect to business performance of gazelles and mice

5 Proposition 5: B\&H business surrounding does leverage neither gazelles nor mice to expand business in the country and abroad.

This framework could be represented by the following figure:

Figure 1 Theoretical framework and propositions

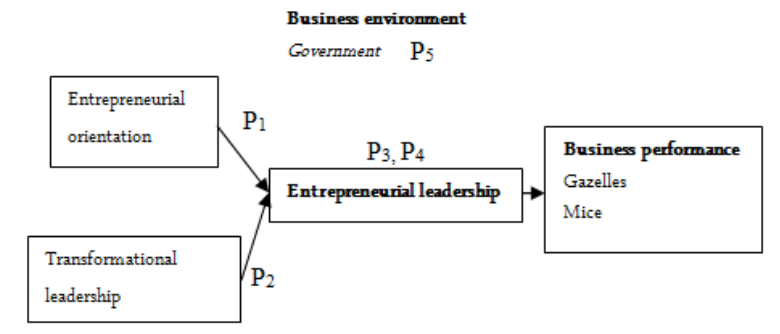

Source: Author's compilation.

\section{Methodology}

\subsection{Reasons for the selected method}

Although the quantitative research is more objective compared with the qualitative, the researcher has decided to undertake this qualitative phonological research and analysis, to make comparison with the quantitative data results from previous studies (Covin and Slevin, 1988; Wiklund and Shepherd, 2003; Palalic and Busatlic, 2015; Bass and Avolio, 1992, 1994, 1996, 1997, 2000). This part is phenomenological in its nature, because the researcher wants to examine in reality, face to face, how certain things are perceived from other practitioners and professionals in business. Creswell (1998) suggests this methodology when people's experience is important and when new views and concepts of the research phenomena are to be discovered (Sanders, 1982; Cohen et al., 2000). The phenomenology is important in this case, because the author will take real insights of the issues in their 'nature' [Van Manen, (1990), p.177]. It is a reflection of the real-life 'experiences' (Von Eckartsberg, 1986; Moustakas, 1994) on certain issues that are inevitable to overlook the issues explored. Since it is an 'interpretive research' (Denzin and Lincoln, 2005), it will significantly describe the two phenomena, entrepreneurial orientation and transformational leadership, in B\&H gazelles and mice that might be correlated to business performance. Sometimes, it is beneficial when it is possible to interpret unforeseen, hidden and disguised things, which might be of key significance in a certain study.

Hence, the main objective is to testify the 'numbers' (results) from previous studies, and to find hidden meanings behind those numbers. Thus, the author chose the purposive stratified sampling, considering it to be the most appropriate for this type of research, for which Hycner (1999, p.156) says: "the phenomenon dictates the method (not vice-versa) including even the type of participants." Similarly, according to Welman and Kruger 
(1999), they suggest that this method is one of the most important non-probability methods in selecting the primary research participants. Also, another reason for choosing this method is due to the internal objective, which is to select people who are familiar with these phenomena [Kruger, (1988), p.150). Therefore, the topic will be clearer and understood, and the participants will be able to discuss and give proper responses. Additional reasons are internal judgment and the purpose of this study (Babbie, 1995; Greig and Taylor, 1999; Schwandt, 1997). However, qualitative research does not impose very strict procedures regarding sampling like quantitative researches do (Coyne, 1997).

\subsection{Sampling, selection of the participants and data collection}

\subsubsection{Sampling}

For this research the author uses stratified purposive sampling method. This is a very convenient, most efficient and valid method in terms of convenience sampling. The main objective of the stratified purposeful sample is not to obtain 'a common view' but to get 'major variations' among strata (gazelles and mice), whereby each of these strata is supposed to represent one 'homogenous sample' [Patton, (1990), p.174]. However, the main difference in comparison to stratified random sampling is that purposive stratified sampling requires a very small sample for 'generalisations or statistical representativeness' [Patton, (1990), p.174]. The sample size differs, but it is usually kept small [Cooper and Schindler, (2014), p.146). To determine the strata for this research, the researcher followed sectors from previous researches of Palalic and Busatlic (2015), from where gazelles and mice were originated. There were three industrial sectors, which are most represented in Bosnia and Herzegovina, manufacturing, sales and services. Based on this, the researcher has chosen five companies from each sector, manufacturing, sales and services. He purposely selected companies to perform interviews, by contacting them via the telephone in order to invite them for interview and arrange a place and time. Out of 30 companies that he contacted for interview, 15 of them agreed to participate. Therefore, the sample size was 15 companies.

\subsubsection{Data collection}

This research is based on the qualitative approach where semi-structured interview is used. The researcher randomly found companies which he considered them as useful for this kind of research. After determining the type of firms which will be interviewed, he has chosen 30 of them to be contacted and arranged interviews. He invited them via telephone and out of 30 of them, 15 were willing to participate. The researcher has arranged a location and time for the interview sessions. The semi-structured interviews were planned according to length, location, recording, and a person to undertake the interview. The interview length was planned from 30-60 minutes. Locations for the interviews were university premises (two out of 15) and locations at each company headquarters. Responses were planned to be recorded in audio form, as well as a written record. However, only one out of 15 agreed for interview to be taped, while 14 of them refused to have the audio record. Therefore, the researcher manually recorded information in written form (either by hand writing or typed on computer); four of them were typed and 11 were hand-written. The following figure summarises the research flow from the beginning until the end. 
Figure 2 Framework for the qualitative research

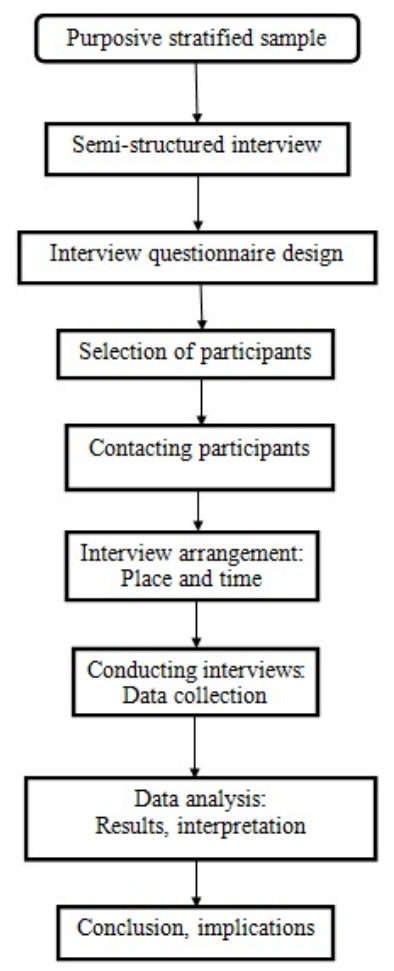

Source: Author's compilation

\subsubsection{Interview type and description of interview questions}

The main technique used in qualitative data collection to obtain the aimed knowledge about something, which can be carried on 'individually or in groups' [Cooper and Schindler, (2014), p.152], is interview. A researcher may undertake unstructuredquestions or discussion topics that are not in an order, semi-structured followed with 'a few specific questions', or structured interview that is very similar to a questionnaire with a very detailed guide for an interviewer. Usually in the qualitative research approach, unstructured or semi-structured interviews are used [Cooper and Schindler, (2014), p.153]. In this research, the researcher used the semi-structured interview. The researcher has adapted questions from two surveys regarding EO dimensions (Covin and Slevin, 1989) and TL style (Bass and Avolio, 1992). He made very simple questions to be very clear for participants. However, respondents were given time and space to elaborate in detail if they wished. Therefore, the interview questions turned to be designed as a combination of 'in-depth and semi-structured' interview approaches. Participants' answers could be as 'agree/not agree; yes/no', or elaborate on their answer in details. Each question is designed in a way to discern an opinion of respondents regarding the relationship between these dimensions and a firm's performance and growth. The Table 1 shows the structure of the interview questions. 
Table 1 Interview questions

\begin{tabular}{lll}
\hline Question & \multicolumn{1}{c}{ Description } & Qualification \\
\hline Question 1 & $\begin{array}{l}\text { Do you think that a firm 's innovativeness may influence a firm's } \\
\text { business performance so that a firm might become a fast growing } \\
\text { company? Would you elaborate on this please? }\end{array}$ & $\begin{array}{c}\text { Innovativeness } \\
\text { influence }\end{array}$ \\
Question 2 & $\begin{array}{l}\text { Do you think that proactiveness could influence a firm's business } \\
\text { performance so that a firm might become a fast growing } \\
\text { company? If yes how, if no why not? }\end{array}$ & $\begin{array}{c}\text { Proactiveness } \\
\text { influence }\end{array}$ \\
Question 3 & $\begin{array}{l}\text { Do you think that a firm, which is a risk taker, may influence a } \\
\text { firm's business performance so that a firm might become a fast } \\
\text { growing company? If yes how, if no why not? }\end{array}$ & $\begin{array}{c}\text { Risk-taking } \\
\text { influence }\end{array}$ \\
Question 4 & $\begin{array}{l}\text { Do you think that charisma can be associated with a firm's } \\
\text { growth? Can you elaborate on this in detail, please? }\end{array}$ & $\begin{array}{c}\text { Individualised } \\
\text { influence }\end{array}$ \\
Question 5 & $\begin{array}{l}\text { Do you think that a firm's atmosphere of treating everyone equal } \\
\text { and capable to do different things may be associated with a firm's } \\
\text { growth? Can you elaborate on this in detail, please? }\end{array}$ & $\begin{array}{c}\text { Intellectual } \\
\text { stimulation } \\
\text { influence }\end{array}$ \\
Question 6 6 & $\begin{array}{l}\text { Do you think that team spirit, enthusiasm and optimism can be } \\
\text { associated with a firm's growth? Can you elaborate on this in } \\
\text { detail, please? }\end{array}$ & $\begin{array}{c}\text { Inspirational } \\
\text { motivation } \\
\text { influence }\end{array}$ \\
Question 7 & $\begin{array}{l}\text { Can and how would 'coaching, mentoring, listening, personalised } \\
\text { interaction, personality differences appreciation' be associated } \\
\text { with a firm's growth? Can you elaborate on this in detail, please? }\end{array}$ & $\begin{array}{l}\text { Individualised } \\
\text { consideration } \\
\text { influence }\end{array}$
\end{tabular}

Question 8 Do you think in an overall context that EO together with TL might Entrepreneurial have a positive correlation with the business growth of SMEs in leadership $\mathrm{B} \& \mathrm{H}$ ? influence

Question 9 What is your view on the following: "fast growing SMEs have a Entrepreneurial greater presence of EO and TL in comparison to slow growing leadership better SMEs in B\&H"? Do you agree? If yes, why? If not, why not? in gazelles vs. mice SMEs development

Question 10 Do you think that the combination of leadership dimensions as well as entrepreneurial orientation dimensions may positively affect both fast and slow growing companies?

Question 11 In the context we discussed, what would you recommend for a SME to become a fast growing firm that will create more jobs in B\&H? Please elaborate.

Entrepreneurial leadership effect

Question 12 Which dimensions would you put in first place, transformational leadership dimensions or entrepreneurial dimensions?

Question 13 Is there anything else that you would like to highlight or add to Miscellaneous this content?

The first question is one of the main questions regarding EO dimension of innovativeness, and its association with a firm's performance and growth. The following two questions are related to proactiveness and risk taking, and their relationship with business performance of the firm. These questions are (1,2, and 3) combined to provide an overall view of entrepreneurial orientation and its association with business performance and growth of a firm. The questions 4,5,6,7 are related to the TL style (individualised influence, intellectual stimulation, inspirational motivation, individualised consideration). Question 8 asks for a respondent's opinion on whether entrepreneurial orientation and transformational leadership are positively correlated to business 
performance and growth of a firm. In question 9, respondents are asked for their opinion on whether the entrepreneurial orientation dimensions and transformational leadership styles are more present in fast growing (gazelles) SMEs compared to slow growing (mice) ones. Question 10 asks respondents whether EO dimensions TL style are important for both gazelles and mice for their growth. In question 11, asks for the best recommendations for B\&H's SMEs to become fast growing firms which will be 'job creators' (Birch, 1979). Question 12 asks participants which phenomenon, either 'EO or TL', is in first place. In other words, what do they think is more important for SMEs to improve their business performance and growth? The last question (13) asks respondents to add anything that might be missing in exploring all these issues are previously examined.

\subsubsection{Data validity}

In terms of data validity in this study, it can be said that the researcher tried to obtain all possible data he needed for this research. Participants not wishing to be interviewed, not willing to answer, feeling stressed and scared to be interviewed, or refusing to tape the interview session indicate that data gathered is poor (Barriball and While, 1994). In this study he only had the chance to be refused for the session to be taped. The justification for this refusal was 'privacy and ethical issues', such that the researcher were requested by participants to not to tape the sessions. In this case, it cannot be said that the data is worthless and should not be to relied on. However, it very often happens that it is not possible to control all circumstances in research (Barriball and While, 1994). Moreover, when the interview sessions were conducted the researcher tried to be as friendly (Patton, 1990) as possible to collect data in written form. As he went further along with the interview sessions, reviews and discussion after the sessions, he became more confident in data collection, which increased data validity for this study (Barriball and While, 1994).

\subsection{Content analysis}

Qualitative data research is used for the purpose of getting deep knowledge about certain issues, related to a particular situation, as well as to explore certain outcomes and why they happened (Cooper and Schindler, 2014). It is also called 'interpretive' research, due to its in-depth description of examined events and issues (Cooper and Schindler, 2014). Following Cooper and Schindler (2014) in this work, the researcher will examine issues related to performance of gazelles and mice through entrepreneurial orientation and transformational leadership. The previous findings have shown importance of the EO dimensions and TL styles in relationship with business performance (Covin and Slevin, 1989; Lumpkin and Dess, 2001; Wiklund and Shepherd, 2005; Yang, 2008, Rao 2012, Aziz et al., 2013a, 2013b, Palalic and Busatlic, 2015). Using this qualitative approach with the semi-structured interview, the author wants to test whether these results are valid from practice; i.e. whether the theory and practice match each other. These results show that gazelles practice more EO dimensions and TL styles compared with mice. Thus, to allow the model for B\&H SMEs to become successful, i.e. gazelles, it is recommended to follow up the practice of examined gazelles. 


\section{Qualitative data analysis and data findings}

\subsection{Overview of the participants}

Among 15 participants, two of them were female (13.3\%) and 12 males $(86.7 \%)$. Three were business owners $(20 \%)$ and 12 of them CEOs $(80 \%)$. In terms of their educational level, seven of them were qualified with an undergraduate degree $(46.7 \%)$ while eight of them $(53.3 \%)^{1}$ possessed a postgraduate degree. All companies fit the SME criteria with a maximum number of employees of 230 and a minimum of 17 . The average was 20 years of existence. In terms of sales, the most significant sales growth was $30 \%$ per annum, and the minimum was $5 \%$. On average, annual sales growth (in last 3 consecutive years) was $12.73 \%$. The age of participants was between 33 (minimum) and 55 (maximum). The average participant's age is 42 . According to sales growth rates, by which gazelles are differ from mice, there were 5 mice and 15 gazelles (this study has followed Davidsson and Henrekson, 2002; Hölzl, 2009; Palalic and Busatlic, 2015, in their stratification of gazelles and mice).

\subsection{Data findings}

The following table represents the results of the qualitative findings on given propositions.

Table 2 Data findings from interviews

\begin{tabular}{lcccl}
\hline Question no & Question ID & Total 'Y/A2' & Total 'N/NA'3 & Responses \\
\hline 1 & Q-INN4 & 14 & 1 & Confirmed \\
2 & Q-PRO5 & 15 & 0 & Confirmed \\
3 & Q-RiT6 & 15 & 0 & Confirmed \\
4 & Q-II7 & 14 & 1 & Confirmed \\
5 & Q-IS8 & 13 & 2 & Confirmed \\
6 & Q-IM9 & 15 & 0 & Confirmed \\
7 & Q-IC10 & 15 & 0 & Confirmed \\
8 & Q8-r+EO+TL11 & 15 & 0 & Confirmed \\
9 & Q11-G $>$ M12 & 12 & 3 & Confirmed \\
10 & Q13-EO + TL $\uparrow 13$ & 15 & 0 & Confirmed \\
\hline
\end{tabular}

The following details were given by each respondent in the research framework of gazelles and mice in $\mathrm{B} \& \mathrm{H}$, with deep insights provided on posed questions. Respondents declared their views from their own experiences and personal observations. The researcher extracted at least one quotation from each sector that might have useful meaning for the posed questions.

The first question on the importance of innovativeness and its influence on a business performance were elaborated as a very important dimension. They argued that there are no 'harsh' (MAN1) rules for applying innovativeness and should be adjusted to each business phase that a firm passes through. Simply, a firm cannot exist in the long term without innovation activities. It must support new ideas and things that lead to success in the long-term (Lumpkin and Dess, 1996). 
For the 2nd question on proactiveness and its relationship to business performance, respondents stressed out that if a firm wants to achieve level of performance as a gazelle it is necessary to encourage proactiveness in a synergetic way. They see proactiveness as a future perspective and there is no alternative for it. It also needs to be adjusted according to current firm's needs ("proactivity approach is important if a firm wants to grow every year. But proactivity as the innovation must be done according to meet necessary needs only - SLS5"). Therefore, to grow every year, a firm must be constantly 'a first mover' in the market (Lumpkin and Dess, 1996).

Risk taking (3rd question) is important and can be related to the business performance of firms, as observed by participants. For entrepreneurial firm a risk dose 'must exist (MAN1)'. Due to market dynamic it is obvious and firm must count on a certain percentage of risk. This is a risk which is thoroughly calculated by the top management. It happens usually when companies see an opportunity by which they may earn higher returns (Trevis et al., 2009). "Without risk, proactiveness and innovation (ideas) there will be no firm's progress" (SLS1).

The 4th question was about transformational leadership style, how and can leadership style (individualised influence) be associated with business performance and growth of firms? The quantitative analyses in previous researches gave a positive significance of TL styles to a change in business performance. Respondents associated transformational leadership, especially charisma, for long-term growth of a firm highlighting the following: "Charismatic people are much more influential and productive" (SER1). "Charisma is very important for the company's growth but it must be in long-term accompanied with leadership and future prosperity for the company and each member of the company" (SLS5).

Intellectual stimulation (5th question) can be expressed in 'creativity' [Bass and Riggio, (2006), p.7] and treating employees capable to do different things; which is important for firms. Most of them responded positively and stressed out its importance for a firm's growth in the long-term. A manager should be wise and observe each intellectual capability and give him a chance to perform associated to his capability. In addition, a 'public criticism' should be avoided [Bass and Riggio, (2006), p.7] in order to keep everybody motivated. Rather, a whole team should be pride as well as criticised.

Inspirational motivation (6th question) as 'team spirit, enthusiasm and optimism' shows its significance as one of the TL styles. One of participants gave us his perception about this issue: "Yes it can! Without team spirit, enthusiasm, optimism and objectives there will be no results. There must be a stimulus that will lead us to positive results" (SLS4). It is obvious that this dimension is an integrated part of 'charismatic-inspirational leadership' [Bass and Riggio, (2006), p.7].

Regarding individualised consideration (7th question) and its contribution and relationship with business performance and growth of an organisation, respondents gave positive opinions on this relationship with business performance of a company. One of them, emphasising its importance, said: "Understanding each employee's needs, their personalities and having a 'tailor made approach' in terms of coaching, interacting, can have a positive impact on their performance" (SLS2). It supports view of Podsakoff et al. (1990), Bass and Riggio (2006, p.7), Jandaghi, 2009) that wise leaders are concerned about their employees regarding their personal feelings and needs.

When respondents were asked in question 8 and question $10^{14}$ for their opinion about whether EO and TL are positively correlated with business performance and growth of gazelles and mice, all of them confirmed it positively related. These results have 
confirmed previous findings on importance of EO dimensions and TL styles in SMEs and positively affect business performance (Miller, 1983; Covin and Slevin, 1988, 1989; Lee et al. 2001; Wiklund and Shepherd, 2005; Su et al. 2011; Zhang and Zhang, 2012; Kraus et al. 2012; Kraus, 2013; Yang, 2008; Chandrakumara et al. 2009; Rao, 2012; Fazli et al. 2012; Aziz et al. 2013a, 2013b). One interesting observation was: "These are closely related and to put these things in the right place is leading to success. There is no EO without TL" (SLS3).

Gazelles and mice are important and somehow gazelles are privileged due to their high annual growth and creation of more jobs (Birch, 1979). In this context respondents were asked to confirm or reject the following statement: "TL and EO are more present in gazelles than in mice" (9th question); 12 of them confirmed this and three of them did not agree with this statement (Table 2).

However, when asked what they would put in first place (12th question), regarding its importance for gazelles and mice, EO or TL, they responded differently. For TL styles as a priority over EO dimensions there were four positive responses, while the EO being the priority five respondents were in favour. Six participants could not distinguish which one is more important and stayed neutral.

The last question (13th question) asked participants to add anything to the topics discussed within the B\&H context that they might have missed. Responses were mostly 'that is it', or 'we discussed already'. However, some of them used the opportunity to extend the discussion and elaborate further. Some of their thoughts are as follows: "In Bosnia we should promote these values we talked about, because young people should think how to create new jobs in the country; Entrepreneurs' education plays important role in all this; Entrepreneurs should appreciate formal education in business, which is in developed countries is very much appreciated; The above fact is why young and educated people cannot move forward" (SER4). This market is specific, complex, unthankful and very difficult to do business; there must be a better Low regulation for SMEs. Taxes are huge!!!! SMEs must have a kind of 'improvisation' which is a combination of all possible ways of sales, exchange goods and services and Low regulation (this Low the cause to go for improvisation). Other reasons are the market itself, buying power, transition period of the country, competition in every business; simply it is a small pond but many crocodiles" (SLS1).

\section{Discussions, conclusions and implications}

Bosnia and Herzegovina needs SMEs, which can create a significant number of jobs, especially those which have fast growth (business performance). In this context, there is an urgent need to develop a future entrepreneurial leadership model. This should be based on a combination of entrepreneurial orientation and transformational leadership, and it will provide a comprehensive understanding of these two important phenomena to leaders and managers. This is because they complement each other in certain areas and phases of the research (Lakshman et al., 2000). Hence, this study has been devoted to make a model for B\&H SMEs (gazelles and mice), which looks forward to being successful in terms of business performance.

The main purpose for the qualitative approach was to achieve research objectives: 
1 examine EO dimensions and TL style as mediating role in sustainable growth of gazelles and mice

2 identify relationship between EO dimensions and TL style

3 managerial implications for top management

4 possible recommendations to the B\&H Government in terms of its strategic moves for SME development.

In order to achieve these objectives, it is planned to utilise qualitative approach, using stratified purposive sampling methodology, while applying semi-structured interview. This stratification was based on the following industrial sectors, manufacturing, services, and sales. Participants were mainly holding managerial positions (leaders in companies).

The results of the interviews recommend us to accept the model, which emphasises the importance of EO and TL in shaping gazelles and mice. In addition, mice should strive to be gazelles through time, because of the huge global competition that surrounds them every day. This research followed Kraus et al. (2012) to examine each EO's dimension separately, as well as TL style, using semi-structured interview, in relationship with business performance. He obtained in-depth information on each dimension and style, to confirm their importance towards business performance. Answers on these interview questions were positive (Table 2). These answers have achieved the first research objective.

The worthwhile literature in terms of EO dimensions (Miller, 1983; Covin and Slevin, 1988; Lee et al., 2001; Wiklund and Shepherd, 2005; Su et al., 2011; Zhang and Zhang, 2012; Kraus et al., 2012; Kraus, 2013) and TL style (Burns, 1978; Bass and Avolio, 1992; 1994; 1996; 1997; 2000; Yang, 2008; Chandrakumara et al., 2009; Rao, 2012; Fazli et al., 2012; Aziz et al., 2013a, 2013b) has been indicated as very significant, and consequently appeared to be important to SMEs' business performance. However, the application of these theories was not related to gazelles and mice, and this study addresses these issues in the context of the questions elaborated earlier. Therefore, within this framework, the researcher has explored these theories to gazelles and mice within the $\mathrm{B} \& \mathrm{H}$ business environment and met the research objectives.

\subsection{Managerial implications}

This research has addressed managerial issues introduced in the objectives of the study. As the previous theories of EO dimensions and TL styles have confirmed their importance, therefore this study stressed the same. EO dimensions are fully confirmed as important as well as TL style. The study implies, suggests and recommends implementation of both phenomena in gazelles and mice for their long-term success. Moreover, if mice want to grow constantly, employment of these two phenomena must be real and fully encouraged by the top management. Due to certain government policies that are irrational such as: managers must 'improvise' their business, in order to manage payables and receivables on time. Yet, they can go to international level if they have cash to pay. Likewise, managers/leaders need to possess a lot of savvy to lead a company in the long-term (liquidity wise), which will be able to compete in the European market. 


\subsection{Government policy implication}

The empirical results of the qualitative data identified that there are very awkward barriers for businesses, which describe the business environment as very 'specific, complex, unthankful and very difficult to do business'. For instance, one respondent commented that 'the taxes are very high'. In addition, respondents also mentioned that it is a 'transition period of the country; competition in every business' and there is low 'buying power'. 'Simply, it is a small pond, but many crocodiles' (SLS1). These reasons cause the market to have unregulated receivables and payables, which may lead to 'improvisation' (and the Law is seen as the main cause of it). Moreover, this improvisation is described by all participants as anything that you would receive for your products, goods and services, but not money. Also, the respondents were open to comment that the State makes the mistake of not improving the current business environment through liberation of tax regulations. Similarly, they state as an imperative for individuals to be educated in the area of entrepreneurship, and that business owners should appreciate educated people who are willing to add value to firms.

Although B\&H did neither consider nor focus on the previous researches as transitional economy (Dana, 1999; Dana and Ramadani, 2015), this confirms that B\&H is in a real transition and it depicts the reality of B\&H's business environment and adds uniqueness to this region as described by Dana (1999).

In this context this study strongly suggests that the "B\&H government should promote (not being neutral or making current situation even worse) the values of entrepreneurial leadership; because young people should think how to create new jobs in the country and Entrepreneurs' education plays an important role in all this". In addition, the Government should emphasise the importance of entrepreneurial leadership, providing opportunity for the public and private sector to be educated more in this area and propose to educational institutions (private and public schools and universities) that entrepreneurial leadership is a must in the educational curricula. In addition, the government's role needs to be more supportive in terms of family business (from which Bosnian entrepreneurial leadership has emerged). This is due to the fact that most of private businesses in B\&H are financed from entrepreneurs themselves, where in case of business failure, their family existence can be negatively affected (Dana and Ramadani, 2015).

Similarly, there is an urgent need for 'better law regulation' that will regulate the things related to companies' 'receivables and payables' of firms. In context, the government should remove barriers to easy entry-exit of new firms. This would create free space to move or to shift from one market segment to another. This is an imperative to follow the rapidly changing business environment around the globe. B\&H's policy makers should leverage development of entrepreneurship, as it is important and imperative for development of the society and economic growth (Ramadani et al., 2015). One of entrepreneurship pillars is innovation and the government should follow other countries in its application and management, like Macedonia, which experiences growing innovation index in last years (Ramadani et al., 2013b; GII report, 2015). B\&H's government should encourage women as entrepreneurs, which could be the topic of future research. Female entrepreneurs are important around the world and even in transitional countries, representing one of the key pillars in the development of society (Ramadani et al., 2013b), B\&H, as one of post the communist countries (Serbia, Slovenia, Macedonia) is last country, which advances entrepreneurship when female 
entrepreneurs are in focus (Ramadani et al., 2015). It might be because of the system which put many slow-downs for the country, in terms of the entrepreneurship, which nowadays is seen as an important factor in society's development (Ramadani et al., 2013a). This fact is true around the world and applies to the countries in transition, as well.

\subsection{Limitations of the research}

Although this research has offered a unique perspective of studying SMEs and shown its importance that can be applied at a national and international market level, however, this study has some limitations that should be considered.

The qualitative approach of data collection was challenged by the selection of participants that would be able to satisfy our objectives of this approach and answer the questions. This prolonged the time frame planned for data acquisition for this type of research. Also, conducting interviews without tape recording can cause important omissions from the interview. Due to country specific factors, like post-war and transition process, these setbacks happen and the researcher could not go beyond the reality.

However, besides these limitations, the methodology, sample size and analyses enabled and impressed us to answer all posed questions and objectives in this study. Moreover, it gave us in-depth insights provided by qualitative data results.

\section{References}

Abazi-Alili, H., Ramadani, V. and Gërguri-Rashiti, S. (2014) 'Determinants of innovation activities and their impact on the entrepreneurial businesses performance: empirical evidence from Central and South Eastern Europe', Third REDETE Conference Economic Development and Entrepreneurship in Transition Economies: Challenges in the Business Environment, Barriers and Challenges for Economic and Business Development, Banja Luka, 10-12 April.

Avolio, J. and Bass, M. (2002) Developing Potential Across A Full Range of Leadership, Cases on Transactional and Transformational Leadership, Lawrence Erlbaum Associates, New Jersey.

Aziz, R.A., Mahmood, R. and Abdullah, M.H. (2013a) 'The effects of leadership styles and entrepreneurial orientation on the business performance of SMEs in Malaysia' The IBEA, International Conference on Business, Economics, and Accounting, Bangkok-Thailand, 20-23 March [online] http://www.caal-inteduorg.com/ibea2013/ejournal/042---Roslan_AAandRosli _MandM_Hussin_A---The_Effect_of_Leadership.pdf (accessed 15 January 2014).

Aziz, R.A., Mahmood, R. and Abdullah, M.H. (2013b) 'The effects of leadership styles and entrepreneurial orientation on the business performance of SMEs in Malaysia' The 2nd IBSM, International Conference on Business and Management, Chiang Mai, Bangkok, 2-4 October.

Babbie, E. (1995) The Practice of Social Research, 7th ed., Wadsworth, Belmont, CA.

Barriball, L.K. and While, A. (1994) 'Collecting data using a semi-structured interview: a discussion paper', Journal of Advanced Nursing, Vol. 19, No. 2, pp.328-335.

Bass, B.M. (1985) Leadership and Performance Beyond Expectation, Free Press, New York.

Bass, B.M. and Avolio, B.J. (1992) Manual for the Organizational Description Questionnaire $(O D Q)$, Consulting Psychologists Press, Palo Alto, CA.

Bass, B.M. and Avolio, B.J. (1994) Improving Organizational Effectiveness Through Transformational Leadership, Sage, Thousand Oaks, CA.

Bass, B.M. and Avolio, B.J. (1996) MLQ Multifactor Leadership Questionnaire for Teams, Mind Garden, Redwood City, CA. 
Bass, B.M. and Avolio, B.J. (1997) Revised Manual for the Multifactor Leadership Questionnaire, Mind Garden, Palo Alto, CA.

Bass, B.M. and Avolio, B.J. (2000) MLQ: Multifactor Leadership Questionnaire, 2nd ed., Mind Garden, Redwood City, CA.

Bass, B.M. and Avolio, B.J. (2001) 'Shatter the glass ceiling: women may make better managers', in Grint, K. (Ed.): Leadership: Classical, Contemporary, and Critical Approaches, Oxford University Press, Oxford.

Bass, B.M. and Riggio, R.E. (2006) Transformational Leadership, 2nd ed., Center for Leadership Studies Binghamton University, Kravis Leadership Institute Claremont McKenna College Lawrence Erlbaum Associates, Publishers, Mahwah, New Jersey.

Bhide, A.V. (2000) The Origin and Evolution of New Businesses, Oxford University Press, New York.

Birch, D.G.W. (1979) 'The job generation process', MIT Program on Neighborhood and Regional Change, Cambridge, MA.

Brown, T.E., Davidsson, P. and Wiklund, J. (2001) 'An operationalization of Stevenson's conceptualization of entrepreneurship as opportunity-based firm behavior', Strategic Management Journal, Vol. 22, No. 10, pp.953-968.

Burns, J.M. (1978) Leadership, Harper \& Row, New York.

Casillas, C.J. and Moreno, M.A. (2010) 'The relationship between entrepreneurial orientation and growth: the moderating role of family involvement', Entrepreneurship and Regional Development: An International Journal, Vol. 22, Nos. 3-4, pp.265-291.

Chan, S.C.H. and Mak, W.M. (2014) 'Transformational leadership, pride in being a follower of the leader and organizational commitment', Leadership \& Organization Development Journal, Vol. 35, No. 8, pp.674-690.

Chandrakumara, A., De Zoysa, A. and Manawaduge, A.S. (2009) 'Leadership styles and company performance: the experience of owner-managers of SMEs', Proceedings of the 4th International Asian Academy of Applied Business, 17th Dec. Asian Academy of Applied Business, Makati City, Philippines, pp.391-401.

Cohen, M.Z., Kahn, D.L. and Steeves, R.H. (2000) Hermeneutic Phenomenological Research: A Practical Guide for Nurse Researchers, Sage, Thousand Oaks, CA.

Cooper, D.R. and Schindler, P.S. (2014) Business Research Methods, 12th ed., McGraw-Hill, New York.

Covin, G.J., Green, K.M. and Slevin, P.D. (2006) 'Strategic process effects on the entrepreneurial orientation-sales growth rate relationship', Entrepreneurship Theory and Practice, Vol. 30, No. 1, pp.57-81.

Covin, J.G. and Slevin, D.P. (1988) 'The influence of organization structure on the utility of an entrepreneurial top management style', Journal of Management Studies, Vol. 25, No. 3, pp.217-234.

Covin, J.G. and Slevin, D.P. (1989) 'Strategic management of small firms in hostile and benign environments', Strategic Management Journal, Vol. 10, No. 1, pp.75-87.

Covin, J.G. and Slevin, D.P.A. (1991) 'Conceptual model of entrepreneurship as firm behavior' Entrepreneurship Theory and Practice, Vol. 16, No. 1, pp.7-25.

Coyne, I.T. (1997) 'Sampling in qualitative research.Purposeful and theoretical sampling; merging or clear boundaries?', Journal of Advanced Nursing, Vol. 23, No. 3, pp.623-630.

Creswell, J.W. (1998) Qualitative Inquiry and Research Design: Choosing Among Five Traditions, Sage, Thousand Oaks, CA.

Dana, L.P. (1999) 'Business and Entrepreneurship in Bosnia and Herzegovina', Journal of Business \& Entrepreneurship, Vol. 11, No. 2, pp.105-117.

Dana, L.P. and Ramadani, V (2015) (Eds.): Family Business in Transition Economies, Springer International Publishing Switzerland, Springer. 
Dana, L.P. and Dana T. (2003) 'Management and enterprise development in post-communist economies', Int. J. of Management and Enterprise Development, Vol. 1, No. 1, pp.45-54.

Davidsson, P. and Henrekson, M. (2002) 'Determinants of the prevalence of start-ups and highgrowth firms', Small Business Economics, Vol. 19, No. 2, pp.81-104.

Denzin, N.K. and Lincoln, Y.S. (2005) 'Introduction: the discipline and practice of qualitative research', in Denzin, N.K. and Lincoln, Y.S. (Eds.): The Handbook of Qualitative Research, 3rd ed., pp.1-32, Sage, Thousand Oaks, CA.

Engelen A., Gupta V.K., Strenger L. and Bretel, M. (2015) 'Entrepreneurial orientation, firm performance, and the moderating role of transformational leadership' Journal of Management, Vol. 41, No. 4, pp.1069-1097.

Fazli, M., Sam, M., Tahir, M.N.H. and Bakar, K.A. (2012) 'Owner-managers of SMEs in IT sector: leadership and company performance', International Journal of Business and Social Science, Vol. 3, No. 14, pp.195-205.

Greig, A. and Taylor, J. (1999) Doing Research with Children, Sage, London.

Gupta, A.K. and Govindarajan, V. (1984) 'Unit effectiveness at strategy implementation', Academy of Management Journal, Vol. 27, No. 1, pp.25-41.

Gupta, V., MacMillan, I.C. and Surie, G. (2004) 'Entrepreneurial leadership: developing and measuring a cross-cultural construct', Journal of Business Venturing, [online] http://dx.doi.org/10.1016/S0883-9026(03)00040-5 (accessed 12 June 2015).

Gupta, V.K. and Batra, S. (2015) 'Entrepreneurial orientation and firm performance in Indian SMEs: Universal and contingency perspectives', International Small Business Journal, DOI: $10.1177 / 0266242615577708$ (forthcoming).

Harms, R. (2009) 'Firm-level entrepreneurship and performance for German Gazelles', International Journal of Entrepreneurial Venturing, Vol. 1, No. 2, pp.185-204.

Harms, R. and Ehrmann, T. (2009) 'Firm-level entrepreneurship and performance for German gazelles', International Journal of Entrepreneurial Venturing, Vol. 1, No. 2, pp.185-204.

Henker, N., Sonnentag, S. and Unger, D. (2014) 'Transformational leadership and employee creativity: the mediating role of promotion focus and creative process engagement', Journal of Business and Psychology, Vol. 30, No. 2, pp.235-247.

Hölzl, W. (2009) 'Is the R\&D behaviour of fast-growing SMEs different? Evidence from CIS III data for 16 countries', Small Business Economics, Vol. 33, No. 1, pp.59-75.

Hughes, M. and Morgan, R.E. (2007) 'Deconstructing the relationship between entrepreneurial orientation and business performance at the embryonic stage of firm growth', Industrial Marketing Management, Vol. 36, No. 5, pp.651-661.

Hycner, R.H. (1985) 'Some guidelines for the phenomenological analysis of interview data', Human Studies, Vol. 8, No. 3, pp.279-303.

Jandaghi, G., Matin, H.Z. and Farjami, A. (2009) 'Comparing transformational leadership in successful and unsuccessful companies', African Journal of Business Management, Vol. 3, No. 7, pp.272-280.

Kearney, E., Gebert, D. and Voelpel, S.C. (2009) 'When and how diversity benefits teams: the importance of team members' need for cognition', Academy of Management Journal, Vol. 52, No. 3, pp.581-598.

Keh, H.T., Nguyen, T.T.M. and Ng, H.P. (2007) 'The effects of entrepreneurial orientation and marketing information on the performance of SMEs', Journal of Business Venturing, Vol. 22, No. 4, pp.592-611.

Knight, G.A. (2000) 'Entrepreneurial and marketing strategy: the SMEs under globalization', Journal of International Marketing, Vol. 8, No. 2, pp.12-32.

Koryak, O., Mole, K.F., Lockett, A., Hayton, J.C., Ucbasaran, D. and Hodgkinson, G.P. (2015) 'Entrepreneurial leadership, capabilities and firm growth', International Small Business Journal, Vol. 33, No. 1, pp.89-105. 
Kraus, S, Rigtering, J.P.C., Hughes, M. and Hosman, V. (2012) 'Entrepreneurial orientation and the business performance of SMEs: a quantitative study from the Netherlands', Review of Managerial Science, Vol. 6, No. 2, pp.161-182.

Kraus, S. (2013) 'The role of entrepreneurial orientation in service firms: empirical evidence from Austria', The Service Industries Journal, Vol. 33, No. 5, pp.427-444.

Kreiser, P.M., Marino, L.D. and Weaver, K.M. (2002) 'Assessing the psychometric properties of the entrepreneurial orientation scale: a multi-country analysis', Entrepreneurship Theory and Practice, Vol. 26, No. 4, pp.71-95.

Kruger, D. (1988) An Introduction to Phenomenological Psychology, 2nd ed., Jut, Cape Town, South Africa.

Kusumawardhani, A., McCarthy, G. and Perera, N. (2009) 'Framework of entrepreneurial orientation and networking: a study of SMEs performance in a developing country', Proceedings of the Australian and New Zealand Academy of Management Conference, Australian and New Zealand Academy of Management, Adelaide, Australia, pp.1-16.

Lakshman, M., Sinha, L., Biswas, M. and Charles, M.N.K. (2000) 'Quantitative vs qualitative research methods', Indian Journal of Pediatrics, Vol. 67, No. 5, pp.369-377.

Lee, C., Lee, K. and Pennings, J.M. (2001) 'Internal capabilities, external networks, and performance: a study on technology-based ventures', Strategic Management Journal, Vol. 22, Nos. 6-7, pp.615-640.

Lee, S.M. and Lim, S. (2009) 'Entrepreneurial orientation and the performance of service business', Service Business, Vol. 3, No. 1, pp.1-13.

Li, Y.H., Huang, J.W. and Tsai, M.T. (2009) 'Entrepreneurial orientation and firm performance: The role of knowledge creation process', Industrial Marketing Management, Vol. 38, No. 4, pp.440-449.

Lumpkin, G.T. and Dess, G.G. (1996) 'Clarifying the entrepreneurial orientation construct and linking it to performance', Academy of Management Review, Vol. 21, No. 1, pp.135-172.

Lumpkin, G.T. and Dess, G.G. (2001) 'Linking two dimensions of entrepreneurial orientation to firm performance: the moderating role of environment and life cycle', Journal of Business Venturing, Vol. 16, No. 5, pp.429-451.

Lumpkin, G.T., Cogliser, C.C. and Schneider, D.R. (2009) 'Understanding and measuring autonomy: an entrepreneurial orientation perspective', Entrepreneurship Theory and Practice, Vol. 33, No. 3, pp.47-69.

Matzler, K., Schwarz, E., Deutinger, N. and Harms, R. (2008) 'Relationship between Transformational Leadership, Product Innovation and Performance in SMEs', Journal of Small Business and Entrepreneurship, Vol. 21, No. 2, pp.139-151.

Michie, J. and Zumitzavan, V. (2012) "The impact of "learning" and "leadership" management styles on organizational outcomes: a study of tyre firms in Thailand', Asia Pacific Business Review, Vol. 18, No. 4, pp.1-24.

Miller, D. (1983) 'The correlates of entrepreneurship in three types of firms', Management Science, Vol. 29, No. 7, pp.770-791.

Morris, M.H. and Paul, G.W. (1987) 'The relationship between entrepreneurship and marketing in established firms', Journal of Business Venturing, Vol. 2, No. 3, pp.247-259.

Moustakas, C. (1994) Phenomenological Research Methods, Sage, Thousand Oaks, CA.

Murphy, G.B., Trailer, J.W. and Hill, R.C. (1996) 'Measuring performance in entrepreneurship research', Journal of Business Research, Vol. 36, No. 1, pp.15-23.

Neumark, D., Wall, B. and Zhang, J. (2011) 'Do small businesses create more jobs? New evidence from the Unites States from the national establishment time series', The Review of Economics and Statistics, Vol. 93, No. 1, pp.16-29.

Noble, C.H., Sinha, R.K. and Kumar, A. (2002) 'Market orientation and alternative strategic orientations: a longitudinal assessment of performance implications', Journal of Marketing, Vol. 66, No. 4, pp.25-39. 
Noruzy, A., Shatery, K., Rezazadeh, A. and Hatami-Shirkouhi, L. (2011) 'Investigation the relationship between organizational justice, and organizational citizenship behavior: the mediating role of perceived organizational support', Indian Journal of Science and Technology, Vol. 4, No. 7, pp.842-847.

O'Regan, N. and Ghobadian, A. (2006) 'Innovation in NTBFs: does leadership really matter?' International Entrepreneurship and Management Journal, Vol. 2, No. 2, pp.299-314.

Palalic, R. and Busatlic, S. (2015) 'Exploratory research on relationship between entrepreneurial orientation styles and business performance and growth of fast and slow growing small and medium enterprises in Bosnia and Herzegovina', International Journal of Business and Management, [online] http:doi.org/10.5539/ijbm.v10n2p15 (accessed 24 February 2015).

Patton, M.Q. (1990) Qualitative Research and Evaluation Methods, 2nd ed., Sage, Newbury Park, California.

Podsakoff, P.M., MacKenzie, S., Moorman, R.H. and Fetter, R. (1990) 'Transformational leadership behaviors and their effects on followers' trust in leader, satisfaction and organizational citizenship behaviors', Leadership Quarterly, Vol. 1, No. 2, pp.107-142.

Ramadani, V., Gërguri, S., Rexhepi, G. and Abduli, S. (2013a) 'Innovation and economic development: the case of FYR of Macedonia', Journal of Balkan and Near Eastern Studies, Vol. 15, No. 3, pp.324-345.

Ramadani, V., Gërguri, S., Dana, L.P. and Tašaminova, T. (2013b) 'Women entrepreneurs in the Republic of Macedonia: waiting for directions', International Journal of Entrepreneurship and Small Business, Vol. 19, No. 1, pp.95-121.

Ramadani, V., Hisrich, R.D. and Gërguri-Rashiti, S. (2015) 'Female entrepreneurs in transition economies: insights from Albania, Macedonia and Kosovo', World Review of Entrepreneurship, Management and Sustainable Development, Vol. 11, No. 4, pp.391-413.

Rao, M.V.K.S. (2012) 'The impact of entrepreneurial orientation and leadership styles on business performance: a study on micro small and medium enterprises', International Journal of Entrepreneurship and Business Environment Perspectives, Vol. 1, No. 2, pp.111-117.

Rauch, A., Wiklund, J., Lumpkin, G. and Frese, M. (2009) 'Entrepreneurial orientation and business performance: an assessment of past research and suggestions for the future', Entrepreneurship Theory Practice, Vol. 33, No. 3, pp.761-787.

Rodrigues, R.G. and Raposo, M. (2011) 'Entrepreneurial orientation, human resources information management, and firm performance in SMEs' Canadian Journal of Administrative Sciences/Revue Canadienne Des Sciences de l'Administration, Vol. 28, No. 2, pp.143-153.

Runyan, R. and Swinney, J. (2008) 'Entrepreneurial orientation versus small business orientation: what are their relationships to firm performance?', Journal of Small Business Management, Vol. 46, No. 4, pp.567-588.

Sanders, P. (1982) 'Phenomenology: a new way of viewing organizational research', The Academy of Management Review, Vol. 7, No. 3, pp.353-360.

Schumpeter, J.A. (1934).Business Cycles: A Theoretical, Historical and Statistical Analysis of the Capitalist Process, McGraw-Hill, New York, NY.

Schwandt, T.A. (1997) Qualitative inquiry: A Dictionary of Terms, Sage, Thousand Oaks, CA.

Shafinaz, A., Rasli, A., Azura, A. and Mohd, Z. (2014) 'The impact of entrepreneurial orientation on business performance: a study of technology-based SMEs in Malaysia', Procedia - Social and Behavioral Sciences, DOI: 10.1016/j.sbspro.2014.04.006.

Stetz, P.E., Howell, R., Stewart, A., Blair, J D. and Fottler, M.D. (2000) 'Multidimensionality of entrepreneurial firm-level processes: do the dimensions covary?', Frontiers of Entrepreneurship Research, Babson College, Wellesley, MA.

Stevenson, H.H. and Jarillo, J.C. (1990) 'A paradigm of entrepreneurship: entrepreneurial management', Strategic Management Journal, Vol. 11, No. 5, pp.17-27.

Su, Z., Xie, E. and Li, Y. (2011) 'Entrepreneurial orientation and firm performance in new ventures and established firms', Journal of Small Business Management, Vol. 49, No. 4, pp.558-577. 
Swiercz, P.M. and Lydon, S.R. (2002) 'Entrepreneurial leadership in high-tech firms: a field study' Leadership \& Organization Development Journal, Vol. 23, No. 7, pp.380-386.

Swierczek, F.W. and Ha, T.T. (2003) 'Entrepreneurial orientation, uncertainty avoidance and firm performance: an analysis of Thai and Vietnamese SMEs', International Journal of Entrepreneurship and Innovation, Vol. 4, No. 1, pp.46-58.

Tajeddini, K. (2010) 'Effect of customer orientation and entrepreneurial orientation on innovativeness: Evidence from the hotel industry in Switzerland', Tourism Management, Vol. 31, No. 2, pp.221-231.

Thomas, A.S. and Mueller, S.L. (2000) 'A case for comparative entrepreneurship: assessing the relevance of culture', Journal of International Business Studies, Vol. 31 No. 2, pp.287-301.

Todorovic, E.W. and Schlosser, F.K. (2007) 'An entrepreneur and a leader!: A framework conceptualizing the influence of leadership style on a firm's entrepreneurial orientation performance relationship', Journal of Small Business \& Entrepreneurship, Vol. 20, No. 3, pp.289-307.

Trevis, S.C., Moss, T.W. and Short, J.C. (2009) 'Entrepreneurial orientation: an applied perspective', Business Horizons, Vol. 52, No. 4, pp.319-324.

Van Manen, V.M. (1990) Researching Lived Experience: Human Science for an Action Sensitive Pedagogy, State University of New York Press, Albany.

Von Eckartsberg, R. (1986) Life-World Experience: Existential-Phenomenological Research Approaches in Psychology, Center for Advanced Research in Phenomenology and University Press of America, Washington, D.C..

Wang, G., Oh., I.S., Courtright, S.H. and Colbert, A.E. (2011) 'Transformational leadership and performance across criteria and levels: A meta-analytic review of 25 years of research', Group \& Organization Management, Vol. 36, No. 2, pp.223-270.

Welman, J.C. and Kruger, S.J. (1999) Research Methodology for the Business and Administrative Sciences, International Thompson, Johannesburg, South Africa.

Wiklund, J. and Shepherd, D. (2003) 'Research notes and commentaries knowledge-based resources, entrepreneurial orientation and performance of small and medium-sized businesses', Strategic Management Journal, Vol. 24, No. 13, pp.1307-1314.

Wiklund, J. and Shepherd, D. (2005) 'Entrepreneurial orientation and small business performance: a configurational approach', Journal of Business Venturing, Vol. 20, No. 1, pp.71-91.

Yang, C.W. (2008) 'The relationships among leadership styles, entrepreneurial orientation, and business performance', Managing Global Transitions, Vol. 6, No. 3, pp.257-275.

Yukl, G. (2010) Leadership in Organizations, 7th ed., Prentice Hall, New Jersey.

Zahra, S. (1991) 'Predictors and financial outcomes of corporate entrepreneurship: An explorative study', Journal of Business Venturing, Vol. 6, No. 4, pp.259-285.

Zahra, S. and Covin, J. (1995) 'Contextual influence on the corporate entrepreneurshipperformance relationship: a longitudinal analysis', Journal of Business Venturing, Vol. 10, No. 1, pp.43-58.

Zhang, Y. and Zhang, X. (2012) 'The effect of entrepreneurial orientation on business performance: a role of network capabilities in China', Journal of Chinese Entrepreneurship, Vol. 4, No. 2, pp.132-142.

Zulfiu, V., Ramadani, V. and Dana, L.P., (2015) 'Muslim entrepreneurs in secular Turkey: distributors as a source of innovation in a supply chain', International Journal of Entrepreneurship and Small Business, Vol. 26, No. 1, pp.78-95.

\section{Websites}

https://www.globalinnovationindex.org/content/page/gii-full-report-2015 (accessed on 29 January 2016). 


\section{Notes}

1 Information of participants' education, we collected after we have finished interviews. This section is not presented in the interview structure.

2 Y means 'yes'; A means 'agree'.

3 N means 'no'; NA means 'not agree'

4 Refers to question number 1 , Table 1.

5 Refers to question number 2 , Table 1.

6 Refers to question number 3, Table 1.

7 Refers to question number 4 , Table 1.

8 Refers to question number 5, Table 1.

9 Refers to question number 6, Table 1.

10 Refers to question number 7, Table 1.

11 Refers to question number 8, Table 1.

12 Refers to question number 9, Table 1.

13 Refers to question number 10, Table 1

14 Question 10 has been posed to re-check answers from question 8. 